\title{
Sexism or gender differentiation and class differentiation in George Bernard Shaw's arms and the man
}

\author{
Fatemeh Azizmohammadi ${ }^{1}$, Zohreh Tayari ${ }^{2}$ \\ ${ }^{1}$ Department of English Teaching, Science and research Branch, Islamic Azad University, Arak, Iran \\ ${ }^{2}$ Department of English Literature, Arak Branch, Islamic Azad University, Arak, Iran
}

Email address:

Azizmohammadi@iau-Arak.ac.ir (F. Azizmohammadi), zohrehtayari57@yahoo.com (Z. Tayari)

\section{To cite this article:}

Fatemeh Azizmohammadi, Zohreh Tayari. Sexism or Gender Differentiation and Class Differentiation in George Bernard Shaw's Arms and the Man. International Journal of Literature and Arts. Vol. 2, No. 1, 2014, pp. 6-9. doi: 10.11648/j.ijla.20140201.12

\begin{abstract}
Before surveying the gender differentiation and class discrimination in Arms and the Man, it will be useful to know something about the Victorian period in England, in which the play was written by George Bernard Shaw. In this period, people live in harsh condition and modernism arrived in England. Working classes tried to develop their social class and condition, but the outstanding idea of that time was: each person who was born in social class can't change his or her class. There were many differences between high and low class of society. For example, the theater was only belonged to the educated people and common people were not allowed to go to the theater or a person from low class can't marry to one from high class. Here George Bernard Shaw as an active member of Fabian society, destroys all of these convictions and insists on the equality of people's income and right especially equality of man and woman in society. The aim of this paper is to study class and gender differentiation in George Bernard Shaw's play, Arms and the man and find the disadvantages of these differences in society.
\end{abstract}

Keywords: Class Differentiation, Gender Differentiation, George Bernard Shaw, Drama

\section{Introduction}

One of the reasons for surveying George Bernard Shaw's play Arms and the Man is that, the play backs to Victorian period that is very important in history of England because in Victorian period England was in the terrible creative conditions. Modernism arrived there, and persons faced to contradiction of old and new beliefs. They lived in harsh conditions. The theater was only belonged to the educated people. Therefore, the artists reflected unbearable condition of life, destructions of families, harshness, and racism in their works, and social realism created to show society in harsh manner and exhibit ugly reality. Social realism is a movement against the romanticism, and classism that exhibits reality as it is without any change. Social realism shows gender discrimination, feeling of loneliness, harshness, sexism, unbearable condition of life, destruction of families, racism, and class differentiation. Class difference, gender difference, brutality, and harshness are more visible than other in this period therefore, the writers and artist depict these conditions in their works. Among them, GeorgeBernard Shaw was the great one who pictures these condition in his plays for he believes that drama is the best way for showing the reality of society and creating change in it. George Bernard Shaw was born in Dublin and joined to the Fabian society after visiting Henrik Ibsen who was the pioneer of realism in theater. Fabian society was the powerful group of British social theorists during the period of 1880 s to 1920 s which was founded formally on January 4, 1884 with R.Pease as secretary. The vital aim of Fabian was controlling the social and economic conditions of society by methods of propaganda and organization and equally of income. The first person who made Fabian society famous was George Bernard Shaw by editing the Fabian Essay (1889). As mentioned before, in social realism, there is insisting on the reality of society even if it is ugly reality. The artist in this school picture the reality of society as it is not as it should be. Here, George Bernard Shaw depicts this reality about class and gender differentiation in his play. George Bernard Shaw shows how women are treated in society and how class differences limited people to develop. In Arms and the Man, class struggle is shown by introducing of play different characters. As a free thinker, George Bernard Shaw supports women's right, equality of income, sharing private property, and change in voting system. Critics, writers, and 
theatre goers recognized him as intelligent and humorous writer. GeorgeBernard Shaw depicts how wealthy men behave with women. For these people there is no difference between high and low class of women. He portrays higher classes that control and role over the lower classes through power, fear, and custom.George Bernard Shaw's ideas about feminism, sexual morality, and classes make the core of this play.

\section{Class Differentiation in Arms and the Man by Shaw}

The Bulgarian society is pictured as feudal class structures that Europe was slowly moving from it. During this period, George Bernard Shaw was writing his plays. In this period, the great changes occurred in advanced countries such as improvement of slums, factory condition, greater representation of lower classes in government gestured the dramatic reform, and working classes had gained the vote and right to education. It also was a time of rising power of middle class. George Bernard Shaw wrote Arms and the Man in Victorian era. He was a keen socialist and had any ideas about classes that exist in Europe. There were some class struggles taking place in Britain as a new wave of socialist ideology. Even if, the country is industrialized, workers and low classes were paid low salary and little security. There were several workers' movements that draw the artists and writers attention such as George Bernard Shaw. In this case, he became socialist and joined Fabian society where he wrote social documents. He believes in the equality of all people and humbles distinction based on social class.

In Arms and the Man, class struggle is shown by introducing of play different characters.Captain Bluntschli represents middle-class. Captain Bluntschli is about thirty four years old. He is a realistic person. He is a professional soldier who is trained in leading the war in best manner. He sees nothing romantic about the violent behavior of human beings during the war. He knows that a dead professional soldier has no value for people therefore; he saved himself by hiding in a lady's bedchamber. He chooses to eat rather than to kill therefore; he carries chocolates rather than guns. He has some features that lead Raina to exchange Sergius with him. His kind and capability endears him to others especially to Petkoff family that was high and noble class of society.

Raina Petkoff is one of the George Bernard Shaw's most happy heroines in his plays. She belongs to high class of society. She is an idealistic person in love with the idea of war and love at the beginning of the play. She enjoys of dramatic entrance. She lives in her dream. Her attraction for Bluntschli is due to the fact that she can separate from the position which limited her and enjoys her life. She shocks her mother when she wants to shock Sergius. George Bernard Shaw writes about Raina:

She has been classified by critics as a minx, a liar; I have nothing to do with that: the only moral question for me is, does she do well or harm? If you admit that she does good, that she generously saves a man's life and wisely extricates her from a false position with another man, then you classify her as you please- brave, generous and affectionate; or artful, dangerous, faithless- it is all one to me....

Raina is combination of all the above qualities. She is romantic. She remembers an opera in which a person shelters an enemy threrfore, she shelters Bluntschli. She marries a person with the soul of a hotel keeper even if, belongs to noble and high class of society.

Raina tells Bluntschli that "her father, Petkoff, is the richest man in the country and he is a major. She says we have only library in Bulgaria" (Act I, 31). Raina is not one that values her inner life, but pays attention to outer appearances, something that is of great importance to her and her family. Without dialogue she is introduced in this way "On the balcony, a young lady, intensely conscious of the romantic beauty of the night, and of the fact that her own youth and beauty is a part of it, is on the balcony, gazing at the snowy Balkans. She is coverd by a long mantle of furs, worth, on a moderate estimate, about three times the furniture of the room" (Act I, 15). Here, it is not important who she is or what she thinks about class position, but it is clear that she refers to the high class and tries to have beautiful appearance.

Sergius Saranoff is a symbol of a romantic hero. He is idealistic, handsome, wealthy, brave, and aristocratic. He becomes hero for his recent victory in war. He shows the features that a noble Bulgarian needs to have. He noticed that wars are not leaded by bravery and courage; they are leaded by capability and practical plans. He tells Louka about his tiresome relationship with Raina who searches ideal of higher love. When Louka reveals all of Riana's mistakes- she has another man in her bedroom- Sergius leads to marry with attractive Louka.

In Arms and the Man, Shaw portrays higher classes that control and role over the lower classes through power, fear and custom. Nicola tells Louka that Petkoff could destroy them. He says "you don't know the power such high people have over the like of you and me when we try to rise out of our poverty against them" (Act III, 22). Nicola is wise but he accepts to be scapegoat of the family or is fired by them. $\mathrm{He}$ has desire to goes out of his positions and improves. He wants to buy a shop in Sofia in order to be independent but "I shall always be dependent on the good will of the family" (Act, II, 22). Louka argues him of "selling his manhood for 30 levas" (Act III, 55).

Louka's wish is higher than Nicola's. She wants to marry noble. She encourages Sergius sense of individualism to defend social convention. On the other side, Sergius loves Louka but he is not allowed to marry her for he is Riana's 
fiancé and they are of different social class. He tries to free himself from expectations and conventions of his class. Nicola teaches her how to behave as high class through her thinking and actions. He teaches her how to make up and clean herself. Petkoff hates middle class like Bluntschli, and Sergius calls Bluntschli "commercial traveler in uniform" (Act II, 30). But they changed their behavior when he solved their problems and inherited hotels of his father.

Louka is angry about the society that leads her to a certain place. Nicola tries to satisfy her that rigid structure of class is part of the natural order of things and people are happy when they obtain their place. He says: "Never you mind my soul; but just listen to my advice. If you want to be a lady, your present behavior to me won't do at all, unless when we are alone. It is too sharp and impudent; and impudence is a sort so familiarity: it shows affections for me. And don't you try being high and mighty with me, either. You are like all country girls: you think it is genteel to treat a servant the way I treat a stable boy the way to get on as a lady is the same as the way to get on as a servant: you have got to know your place: that is the secret of it"(Act III,68). Catherine is another character who makes division between her family and the servants, while play attacks division of ranks. Petkoff thinks that having library is a sign for showing that he is wealthy. When he asks Catherine about using bell in library instead of shouting, she says that civilized and high class people never shout. They did not know what politeness is, they are learning proper habits.

Catherine: you are a barbarian at heart still, Paul. I hope you behaved yourself before all those Russian officers.

Petkoff: I did my best. I took care to let them know that we have a library.

Catherine: ah; but you didn't tell them that we have an electric bell in it? I have had one put up.

Petkoff: what is an electric bell?

Catherine: you touch a button; something tinkles in the kitchen; and then Nicola comes up.

Petkoff: why not shout for them?

Catherine: civilized people never shout for their servants. I have learnt that while you were away.

Petkoff: well, I'll tell you something I have learnt too. Civilized people don't hang out their washing to dry where visitors can see it; so would better have all that [indicating the clothes on the bushes] put somewhere else.

Catherine: oh, that's absurd, Paul: I don't believe really refined people notice such things (Act II, 39)

Therefore, readers by this description can understand class distinction from the bigining of the play.

\section{Gender Differentiation}

In reading a George Bernard Shaw's play, Arms and the Man, one should pay attention to difference between characters of social class and gender or sexes. George Bernard Shaw pictures gender role in characters, Louka, Catherine, Sergius, and other. There is masculinity in Louka's character while annoying Nicola. She reveals her control through her interaction with Sergius. Mrs. Petkoff also shows masculinity in controlling house hold works in absence of her husband Mr. Petkoff. In first act of the play, Raina is threaded by Bluntschli who runs and escapes form soldiers. He threatens a defenseless woman with his gun and allows her to hide him behind the curtain.

Raina: Who's there? Who's there? Who is that?

A man's voice: (in the darlcness, suhduedly, but threatening)

Sh-sh! Don't call out or you'll be shot. Be good; and no harm will happen to you.

Remember. If you raise your voice my pistol will go off.

Raina: Yes.

Man: Well, I don't intend to get killed if I can help it.

Do you understand that?

Raina: I suppose not.

Some soldiers, I know, are afraid of death.

Man: All of them, dear lady, all of them, believe me. It is our duty to live as long as we can, and kill as many of the enemy as we can (Act I, 10).

Nicola is a principle male servant of Petkoff household and Louka is beautiful maid and Nicola's fiancée. Nicola has his ambitions and wants to be a businessman. When he realized that Sergius has romantic desire to Louka, he decided to have Louka as a customer rather than a wife. So he encourages her to engage with Sergius. "Louka: I believe you would rather be my servant than my husband. You make me more out of me. Oh, I know that soul of yours. I must believe in my own way. [Sergius comes in. he checks himself a moment on seeing Louka; then goes to the stove]. Nicola: oh, sir, thank you kindly. I was speaking to this foolish girl about her habit of running up here to the library whenever she gets a chance, to look at the books. That's the worst of her education sir: it gives her habit above her station. Louka: without looking at Sergius, begins to arrange the papers on the table. Sergius: looks at her sleeve and says shall I cure it? Louka: you can't cure it now. Sergius: quite sure? [He makes a movement as if to take her in his arms](Act III, 61).

George Bernard Shaw believes Nicola used Louka as an object for gaining his wish as Blunschli who used Raina as an object to save himself. Here, Shaw illustrates the condition of women in society and the way they are behaved by men. Nicola is satisfied for achieving a 
customer like Louka in his business rather than worry about his fiancée. He is ready to separate from Louka and encourage her to do it only for his ambitions. On the other side, Sergius prefers Louka to Raina when noticed Riana's hidden secret of chocolate cream soldier. He announced his engagement with Louka who is a lady like Raina now. Again, Shaw says that "Sergius utilized Louka as a mean for understanding Riana's secret when Raina was in the way of going out of house.

The structure of act II is more serious. Mr. Sergius tries to make love with Raina but she leaves the room and Louka enters. She tells Raina secret to him without saying the name of his rival. Sergius tries to understand it while he accidently bruises Louka's arm. He apologizes but Louka asks him to kiss her arm.

Sergius: who is my rival?

Louka: A gentleman has no right to hurt a woman under any circumstances. I beg your pardon.

Sergius: That sort of apology may satisfy a lady. Of what use is it to a servant?

Louka: No, I want my hurt made well (Act II, 41).

Mrs. Petkoff also shows masculinity in controlling house hold works in absence of her husband Mr. Petkoff. It can be understad of servants's conversation.

Nicola: Be warned in time, Louka: mend your manners.I know the mistress. She is so grand that she never dreams that any servant could dare to be disrespectful to her; but if once suspects that you are defying her, out you go.

Louka: I do defy her. I will defy her. What do I care for her?

Nicola: If you quarrel with the family, I never can marry you. It's the same as if you quarrelled with me!

Louka: You take her part against Jlle, do you? (Act II, 25).

George Bernard Shaw further shows the vulgarity and impoliteness of the Petkoff towards women when Raina explains that Bulgarians of good standing people in our position wash their really hands nearly every day or the time, Petkoff blames his wife's chronic sore throat on washing her neck every day. "Catherine: Oh, my usual sore throats; that are all. Petkoff: [with conviction] that comes from washing your neck everyday. I have often told you so" (Act II, 38). His lecture on the foolishness of frequent bathing is a sign from George Bernard Shaw that how wealthy men behave with women. For these people there is no difference between high and low class of women.

\section{Conclusion}

It is important to read carefully the play, Arms and the Man because it shows how much situations can affect life, thought, and behaviors of individuals of society which reflects in literature of that era. Many of writers in these period, posed women as victims or decoration, but George Bernard Shaw created intelligent, brilliant, and forceful female characters in control of their own destinies despite the social forces of that time in which he was writing. Sean O'Casey in his book A whisper about George Bernard Shaw writes "Shaw's main fight, armed with all his logical art and wit, was to force forward a system of thought that would, in the longer short run, evolve a sane and sensible life for all" (O’Casey, 1899: 42). .What makes George Bernard Shaw as great playwright refers to his attention to reality of society. During his writing, he pictures reality of society as it is. He chooses drama as a vehicle for showing the reality. He follows the main idea of Fabian Society that is equally of people and income. On the whole, in George Bernard Shaw's view both man and woman have their own private imagination. Both are born equal. It is completely natural that people have positive and negative qualities. So, in his view people are equal and there are no class differences in society.

\section{References}

[1] Abrams, M.H, Galt Harpham. (2009). Geoffrey, A Glossary of Literary Terms, International Student Edition, USA. p.302-03.

[2] Dr. Suleiman, Azher.(2012). G.B. Shaw, Mena for Printing and Publishing-Baghdad.

[3] Smith, Nicola. (2011). Analysis of Social Context of Arms and the Man by G.B.Shaw, Fictionno Comments Print.

[4] Dr. Henderson, Archibald. (1911). G.B.shaw His Life and Works A Critical Biography, Stewart and Kidd Company Cincinnati.

[5] Outhwaite, William.(2006).The Black Well Dictionary of modern Social Thought, Black well publishing LTD.

[6] Ahmad, Manawar Iqbal, Sheeraz Muhammad "Social Realism in Pakistani Short Story Genre", International Islamic University, 2013, Vol.4, No.2

[7] Ajtony, Zsuzsanna, 2012, Britain and Britishness in G.B.shaw's Plays, Cambridge Scholars Publishing.

[8] Griffith, Gareth, 2003, Socialism and Super Brain, The political Thought of G.B.Shaw, Taylor, E-Library

[9] O'Brien, Jodi, 2009, Encyclopedia of Gender and Society, Sage Publication, Inc, Vol.1, 2

[10] Sean.O'Casey, 1899, A wispher about G.B.Shaw, University of America Press 